\title{
Preliminary results from measurements of selected trace metals in the snow-firn pack on Ürümqi glacier No.1, eastern Tien Shan, China
}

\author{
LI Zhongqin, LI Chuanjin, LI Yuefang, WANG Feiteng, LI Huilin \\ Key Laboratory of Cryosphere and Environment/Tianshan Glaciological Station, Cold and Arid Regions Environmental \\ and Engineering Research Institute, Chinese Academy of Sciences, Lanzhou 730000, China \\ E-mail: lizq@Izb.ac.cn
}

\begin{abstract}
We present preliminary results on the occurrence of $\mathrm{Pb}, \mathrm{Cd}, \mathrm{Zn}, \mathrm{Al}$ and Fe in dated samples collected from snow-firn packs at an altitude of $4130 \mathrm{~m}$ on Ürümqi glacier No. 1, eastern Tien Shan. Extreme precautions for avoiding contamination were taken throughout the sampling, processing, transportation and analysis procedures. The concentrations of trace metals were determined by a double-focusing inductively coupled plasma mass spectrometer in an ultra-clean room. The average concentrations for these metals in surface snow are $\left(\right.$ in $\left.\mathrm{ng} \mathrm{g}^{-1}\right): \mathrm{Pb}, 2.4 ; \mathrm{Cd}, 0.05 ; \mathrm{Zn}, 10.0 ; \mathrm{Al}, 100.0$; and $\mathrm{Fe}, 130.0$. These are higher concentrations (especially for $\mathrm{Pb}$ and $\mathrm{Zn}$ ) than those in the polar and/or lowlatitude remote areas. The data show that the input of trace metals to the snow has a clear seasonal change. Lower concentrations in surface snow can be found in July through September and higher concentrations from October to March, with an exception for January. The mean concentrations of the elements in the snow-firn pack also indicate seasonal variations and show a marked inverse relationship with temperature, possibly a result of meltwater percolation in the snow-firn pack.
\end{abstract}

\section{INTRODUCTION}

Trace metals captured in permanent snow can be used as tracers of air mass transport, revealing the history of local and global pollution (Xiao and others, 2001). Since the late 1960s, efforts to measure trace metals, mostly $\mathrm{Pb}$ (also $\mathrm{Cd}$, $\mathrm{Cu}, \mathrm{Hg}, \mathrm{Zn}$ and others in some cases), have been made for polar snow and ice cores (e.g. Murozumi and others, 1969; $\mathrm{Ng}$ and Patterson, 1981; Boutron and Patterson, 1986). For example, for Greenland, there are now comprehensive reliable data on changes in the occurrence of various heavy metals in snow and ice for a wide range of time periods including the last climatic cycle, Greek, Roman and medieval times, the period immediately after the industrial revolution, and the past few decades (Boutron, 1990; Candelone and others, 1995). For Antarctica, the level of $\mathrm{Pb}$ is relatively low for two main reasons: (1) Antarctica is physically remote from the pollution sources of the Northern Hemisphere, with no local sources of pollution, and (2) the barrier effect of the Antarctic Polar Front (Wolff, 1990). In recent decades, there has been an increasing interest in trace metals in high-altitude glaciers in the mid- to low-latitude areas (e.g. Van de Velde and others, 2000; Xiao and others, 2001). Comprehensive datasets have been obtained from the European Alps (e.g. Van de Velde and others, 2000), tropical areas (Ferrari and others, 2001) and the Tibetan Plateau (Xiao and others, 2001). Since the 1970s, Pb in ice and snow has shown a declining trend (Wolff and others, 1988), probably due to the reduced use of lead-containing gasoline.

To investigate the effects of depositional processes and meltwater-related post-depositional processes on chemical species in the snow-firn pack a research program, the Program for Glacier Processes Investigation (PGPI), was launched on Ürümqi glacier No. 1 (UG1), eastern Tien Shan, China, in July 2002 (Li and others, 2006). PGPI aims to obtain comprehensive data on changes in the occurrence of $\mathrm{Pb}, \mathrm{Cd}, \mathrm{Zn}, \mathrm{Al}$ and $\mathrm{Fe}$ in the remote eastern Tien Shan region where there has been a lack of reliable trace metal data. These metals are of great environmental interest because the atmospheric cycles are significantly influenced by Asian dust storms and human activities in the area (Lee and others, 2003). The data are discussed in the light of available information on the sources, variations in different seasons and elution in the snowpack.

\section{SAMPLING AND EXPERIMENTAL TECHNIQUES}

\section{Site description}

The eastern Tien Shan, situated in the central region of the Eurasian continent, is surrounded by many large mountains and vast arid areas (Wang and Zhang, 1985). A westerly jet stream prevails high above the mountains, while the mountain topography converts the westerly into cyclonic and anticyclonic circulations up to $4000 \mathrm{~m}$ (Fig. 1). Near the surface, local valley winds prevail from March through September (Zhang and others, 1994).

UG1 $\left(43^{\circ} 06^{\prime} \mathrm{N}, 86^{\circ} 48^{\prime} \mathrm{E}\right)$, which is situated in the eastern Tien Shan at the headwaters of the Ürümqi river in the Xinjiang Uyger Autonomous Region, China, consists of two smaller glaciers: the east branch and the west branch. The total area of UG1 is currently $1.73 \mathrm{~km}^{2}$; the east and west branches are 1.12 and $0.61 \mathrm{~km}^{2}$, respectively. The equilibrium line averaged around $4055 \mathrm{~m}$ a.s.l. from 1959 to 2003. The mean annual precipitation is approximately $640 \mathrm{~mm}$ and the main precipitation period occurs from May to September, accounting for about $90 \%$ of the annual precipitation. The sampling site, at $4130 \mathrm{~m}$ a.s.l., is located in the percolation zone of the east branch, where the mean annual temperature is approximately $-9.0^{\circ} \mathrm{C}$. Concurrent with precipitation, ablation also occurs from May to September. The depths of the snow pits varied seasonally, with the maximum, $\sim 3 \mathrm{~m}$, occurring in spring and the minimum, $\sim 1.5 \mathrm{~m}$, in late summer. Ürümqi, the provincial 


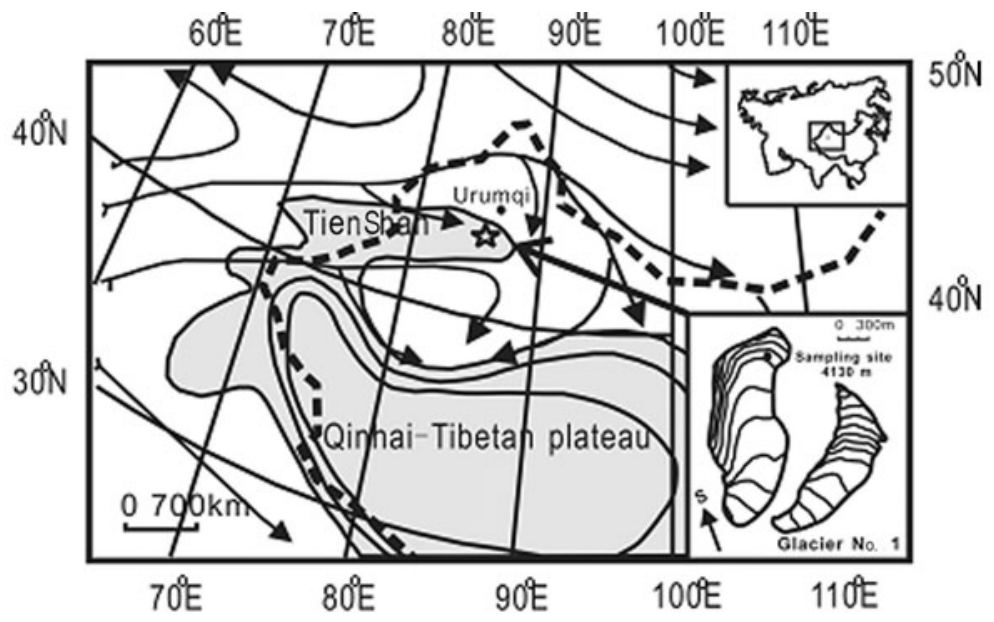

Fig. 1. Mass air trajectory at $1500 \mathrm{~m}$ above the Tien Shan and surrounding area in spring seasons 1960-69 (modified from Li, 1991). The star indicates the location of UG1, which is shown in the inset including the sampling site for the PGPI. The dashed curve indicates national boundaries.

capital of Xinjiang Uyger Autonomous Region with over two million inhabitants, is $105 \mathrm{~km}$ east of UG1. Houxia, a small town where a cement plant has been in production since 1958, lies $50 \mathrm{~km}$ away to the northeast (Lee and others, 2003). In addition, the Ürümqi-Kuerler road, with sporadic traffic, is located on the southern side of UG1.

\section{Sampling and analytical procedures}

All equipment used for field sampling was extensively precleaned by successive 24 hour soaks in a sequence of six acid baths using ultra-pure water and acid inside a specially designed clean room (Boutron and others, 1991; Hong and others, 2000) in the Key Laboratory of Ice Core and Cold Regions Environment, Lanzhou, China. Equipment was airdried in a class 100 ultra-clean chamber and then sealed in two layers of clean polyethylene bags until sampling (Hong and others, 2000).

Two types of samples were collected at the PGPI sampling site: surface snow samples (SF) and snow-firn pack (SP) from snow pits. For SF samples, whenever logistically possible, fresh snow and well-preserved surface snow (i.e. snow that was not affected by post-depositional processes such as sublimation or melting) were collected at the sampling site to investigate the chemical seasonality in precipitation and dry deposition. During the winter, when there was insufficient snowfall, we usually sampled the topmost $3 \mathrm{~cm}$. However, if an accumulation event occurred prior to the sampling, we collected the top $1 \mathrm{~cm}$ of the fresh snow. During the summer, there was usually sufficient fresh snow available, and samples from accumulation that was no more than 2 days old were usually collected from the top $3-5 \mathrm{~cm}$.

For SP samples, one reference snow-firn pit was dug and snow-pit samples were recovered year-round on a monthly basis. The pit was sampled from top to bottom in $10 \mathrm{~cm}$ increments. After each session, the pit was refilled and it was re-excavated during the next session. The wall was then scaled back by at least $50 \mathrm{~cm}$ before the next round of sampling. From September 2002 to September 2003, the snow pit was sampled 13 times to provide 113 snow-pit samples in total. Extreme precautions to avoid contamination were taken throughout the sampling and transportation procedures (Boutron and others, 1991). The samplers dressed in full clean-room clothing (coverall, hood, boots and polyethylene gloves) (Qin and others, 1999). The snow in the upper layers was collected with the sampling bottles pushed into the wall of the snow-firn pack horizontally. When the snow was too hard for the bottle to be inserted, a polyethylene scoop was used. The bottles were sealed in two layers of polyethylene bags after sampling. All snow samples were kept frozen in the field, during transportation and in the laboratory until analysis.

$\mathrm{Pb}, \mathrm{Cd}, \mathrm{Zn}, \mathrm{Al}$ and Fe from the 113 samples were determined in the laboratory. Ultra-pure water (18.2 M $\Omega$ Milli-Q) and $\mathrm{HNO}_{3}$ were used to clean the laboratory equipment and for preparation of standard solutions. All samples were acidified with $0.5 \% \mathrm{HNO}_{3}$ (e.g. $1 \mathrm{~mL} 0.5 \%$ $\mathrm{HNO}_{3}+9 \mathrm{~mL}$ sample; the $0.5 \% \mathrm{HNO}_{3}$ was diluted from $60 \% \mathrm{HNO}_{3}$, 'Ultrapur') just after the snow and ice samples melted, to make $0.5 \%$ solution with $\mathrm{pH}<2.0$. They were then immediately refrozen. This preparation method has been commonly used for snow and ice samples in various regions (e.g. Van de Velde and others, 1998, 1999, 2000; Barbante and others, 1999, 2001, 2003, 2004; Ferrari and others, 2001; Veysseyre and others, 2001; Li and others, 2006). It is important to note that these samples are operationally defined as acid-leached, rather than digested. In order to prevent particle introduction into the plasma, acidified samples were melted again and then centrifuged. Metal concentrations were determined immediately using an inductively coupled plasma mass spectrometer (ICP-MS). Generally only the upper section of the sample in the sample tube was introduced into the ICP-MS, to ensure mineral particles were not introduced into the ICP-MS source. The analyses were immediately performed in another class 100 ultra-clean chamber by double-focusing ICP-MS (DF-ICPMS; Finnigan MAT, Element). These methods have been described by Li and others (2006). The detection limits for the five metals are (in picograms per gram, $\mathrm{pg} \mathrm{g}^{-1}$ ) $\mathrm{Pb}, 0.4$; Cd, 0.4; Zn, 16.7; Al, 427; and Fe, 220. Concentrations of these elements in the samples were all much higher than the detection limits. The precision of the measurements, expressed in relative standard deviation, obtained from one sample of 27 September 2002 were: $\mathrm{Pb}, 0.9 \%$; $\mathrm{Cd}$, $3.4 \% ; \mathrm{Zn}, 4.7 \%$; Fe, 3.7\%; and $\mathrm{Al}, 2.3 \%$. The accuracy of the method was evaluated by analyzing a Standard Reference Material SRM-1640 (Trace elements in natural 


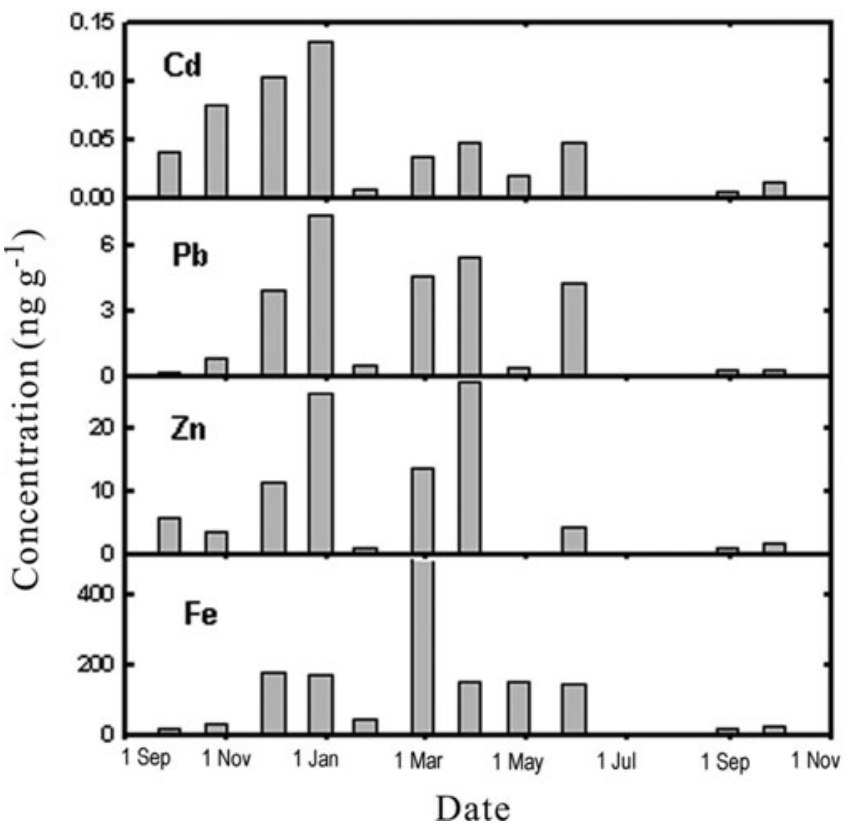

Fig. 2. Temporal variations of the trace metals captured in the surface snow on UG1 during 2002 and 2003. Data for snow with significant elution in July and August are excluded.

water, National Institute of Standards and Technology, USA), after a 50:1 dilution with 1\% $\mathrm{HNO}_{3}$ (diluted from 60\% Merk 'Ultrapur' $\mathrm{HNO}_{3}$ with Milli-Q Element ultra-pure water) solution. The results obtained for selected metals, together with certified values (in parentheses), are $\left(\mathrm{ng} \mathrm{g}^{-1}\right)$ : $\mathrm{Pb}, 27.4 \pm 0.3(27.9 \pm 0.1) ; \mathrm{Cd}, 23.8 \pm 0.3$ (22.8 \pm 1.0$) ; \mathrm{Zn}$, $54.3 \pm 0.1$ (53.2 \pm 1.1$) ; \mathrm{Al}, 51.4 \pm 2.6(52.0 \pm 1.5) ;$ and Fe, $34.0 \pm 0.6(34.3 \pm 1.6)$. Our data agree well with certified values for selected metals.

\section{RESULTS AND DISCUSSION}

\section{Character of the data}

Concentrations of the trace metals captured from UG1 snowfirn packs are presented in Table 1. To our knowledge, they are the first trace metal data published for the eastern Tien Shan. The data are for two types of samples: the concentration in the surface snow (SF) and the average concentration in the snow-firn pack (SP). Generally, in the summer season, the surface snow samples contain mainly fresh snow because there is sufficient snowfall in this period. During the winter, however, when precipitation is sporadic, surface snow undergoes more post-depositional processes including dry deposition, wind erosion, sublimation and condensation.
Measured concentrations in samples of SF are found to differ by orders of magnitude from one metal to another (Table 1). The highest concentrations fall in the $\mathrm{mg} \mathrm{g}^{-1}$ range, for $\mathrm{Al}$ and $\mathrm{Fe}$, which are major constituents of crustal material (Wedepohl, 1995). The lowest concentrations fall in the $\mathrm{pgg}^{-1}$ range, for $\mathrm{Cd}$, which occurs at very low concentration in crustal material.

For all the metals, SP shows much higher concentrations than SF (Table 1). One possible reason for this is that the surface snow had a short time exposure to dry deposition. Both field observations and laboratory measurements showed that SP samples, which included dust layers, were enriched in the metals shown in Table 1 (Wang and others, 2006), resulting in mean concentrations much greater than those of SF samples.

\section{Temporal variations}

The concentrations of the trace and major metals in SF showed an apparent seasonality (Fig. 2). All the metal concentrations were high in late autumn (October to December) and again in mid-winter (February to April), after a low concentration in January. Strata with low concentrations, corresponding to those seen in January in this study, have also been reported in other glacier snowpacks in Asia, such as from Abramov glacier in the Alai-Pamir, where some strata had low metal concentrations and some high concentrations (Hinkley and others, 1997). For Fe, the peak appeared 2 months later than the maxima of $\mathrm{Pb}, \mathrm{Cd}$ and $\mathrm{Zn}$. In summer, all concentrations are lower than the January minimum.

The seasonal variability of chemical compositions of SF was found to reflect seasonal inputs of impurities from the atmosphere, which are closely associated with climatic and environmental characteristics in the region. Three potential sources, local-plus-regional, long-distance and anthropogenic, are likely to be responsible for most chemical substances within SF on UG1 (Li and others, 2006). Potential sources for major metals include local/regional mineral aerosols entrained in the atmosphere by the strong winds that prevail during spring along with a more regional Asian dust flux. Research has shown that local exposed bedrocks and glacial sediments are enriched in hydromica and chlorite containing Fe and Al (see, e.g., Luo, 1983; Chen, 1985). The higher concentration of trace metals during late autumn and winter may be associated with anthropogenic pollution that includes emissions from fossilfuel combustion; coal and other fossil fuels are widely used for heating during these seasons. Atmospheric pollutants from Ürümqi may be transported to the glacier by low-level regional atmospheric circulation. Clouds from factories in

Table 1. Average concentrations and standard deviation of metals in the surface snow (SF) and snow-firn pit (SP) recovered during September 2002 to September 2003 on UG1

\begin{tabular}{|c|c|c|c|c|c|c|c|c|c|c|}
\hline & \multicolumn{2}{|c|}{$\mathrm{Pb}$} & \multicolumn{2}{|c|}{$\mathrm{Cd}$} & \multicolumn{2}{|c|}{$\mathrm{Zn}$} & \multicolumn{2}{|c|}{$\mathrm{Al}$} & \multicolumn{2}{|c|}{$\mathrm{Fe}$} \\
\hline & SF & SP & SF & SP & SF & SP & SF & SP & SF & SP \\
\hline Mean concentration $\left(\mathrm{ng} \mathrm{g}^{-1}\right)$ & 2.4 & 19.3 & 0.05 & 0.3 & 10.0 & 24.6 & 100.0 & 612.5 & 130.0 & 779.0 \\
\hline Standard deviation $\left(\mathrm{ng} \mathrm{g}^{-1}\right)$ & 2.6 & 31.8 & 0.05 & 0.7 & 9.9 & 37.2 & 156.1 & 980.6 & 124.6 & 1339.3 \\
\hline Number of samples & 11 & 110 & 11 & 113 & 10 & 102 & 11 & 110 & 11 & 110 \\
\hline
\end{tabular}


Houxia drift into the river valley and periodically reach UG1, transported by valley winds (Wake and others, 1992; Lee and others, 2003). However, these potential sources need further investigation. Another possible reason for higher metal concentrations in late autumn and winter is that SF has longer time exposure to dry deposition during this dry season.

\section{Spatial comparisons}

The SF metal concentrations from UG1 and some other remote areas are shown in Table 2. The three studies chosen for comparison used nearly identical collection, processing and analytical procedures. The concentrations in Greenland ice-sheet samples are much lower than in UG1 samples. The snow collected from the European Alps and the Himalaya (Tibetan Plateau) show similar $\mathrm{Pb}$ concentrations and both are much lower (35 and 40 times, respectively) than for UG1. Except for the Himalaya, Cd concentrations are significantly higher than for other snow/ice reported, and more than 10 times the lowest concentration in Greenland surface snow. UG1 exhibited Zn concentrations 47 times higher than in Greenland, and Zn in the Alps is also about 10 times lower than in UG1. For Fe the concentrations shown in fresh snow from UG1 are similar to those from the Alps. The much higher metal concentrations on UG1 appear to be associated with the dust aerosol input derived by strong winds from the vast arid and semi-arid areas in central Asia. Local pollution may also be a source, and abundant mineral dust aerosol can act as a carrier to transport these pollutants ( $\mathrm{Li}$ and others, 1995, 1999).

\section{Crustal enrichment factors}

In order to compare the contribution of rock and soil dust with that of other sources, it is helpful to express the metal concentrations in the snow in the form of crustal enrichment factors $\left(\mathrm{EF}_{\mathrm{C}}\right) \cdot \mathrm{EF}_{\mathrm{C}}$ is usually defined as the concentration ratio of $\mathrm{Al}$ (based on the hypothesis that crustal material is the only source of $\mathrm{Al}$ ) normalized to the concentration ratio characteristic of the mean upper continental crust (Wedepohl and others, 1995; Ferrari and others, 2001). For example, the crustal enrichment factor for $\mathrm{Cd}$ is:

$$
\mathrm{EF}_{\mathrm{c}}(\mathrm{Cd})=[\mathrm{Cd} / \mathrm{Al}]_{\text {snow }} /[\mathrm{Cd} / \mathrm{Al}]_{\text {meancrust }} .
$$

Many researchers suggest that $\mathrm{EF}_{\mathrm{C}}$ values within \pm 10 times the mean crustal abundance (i.e. values ranging from $\sim 0.1$ to 10) indicate a dominant input from rock and soil dust, as some dust source regions may have elemental concentrations larger than in average crust, due to natural, longterm processes (Riemann and de Caritat, 2000). Conversely, $\mathrm{EF}_{\mathrm{C}}$ values significantly larger than $\sim 10$ may suggest a

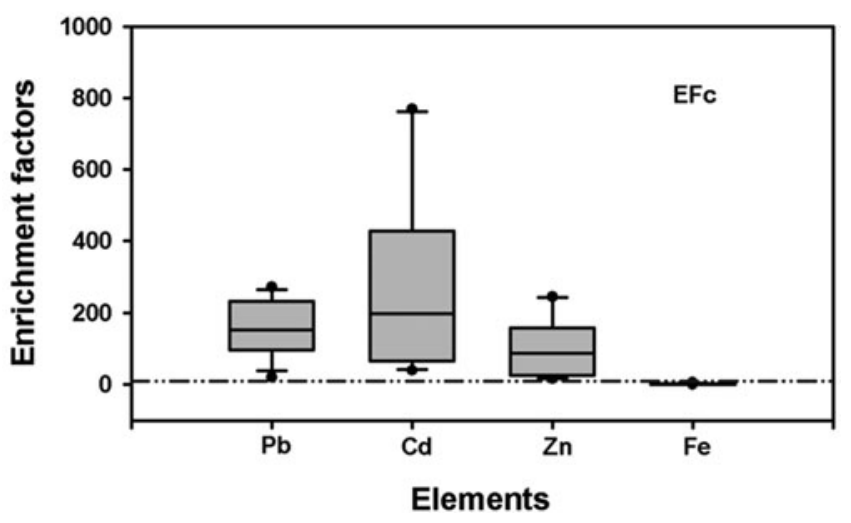

Fig. 3. Plots of crustal enrichment (relative to $A I)$ factors $\left(E F_{C}\right)$ for snow-firn pack samples from UG1 covering the period September 2002 to September 2003. The dashed line indicates $\mathrm{EF}_{\mathrm{C}}=10$.

pronounced contribution from other sources (i.e. anthropogenic) (Halstead, 2000; Ferrari and others, 2001; Barbante and others, 2003).

Figure 3 shows that $\mathrm{EF}_{\mathrm{C}}$ values are very different among the trace elements, highlighting the commonly observed difference in $\mathrm{EF}_{\mathrm{C}}$ between major rock-forming metals such as $\mathrm{Fe}$, and trace elements such as $\mathrm{Pb}, \mathrm{Cd}$ and $\mathrm{Zn}$. $\mathrm{EF}_{\mathrm{C}}$ values between $\sim 20$ and 770 are observed for almost all trace metals, especially during the winter, when $\mathrm{EF}_{\mathrm{c}}$ values are greater than 200. The element with the lowest $\mathrm{EF}_{\mathrm{C}}$ values is $\mathrm{Fe}(\sim 1$ to 6$)$, suggesting that a significant portion of Fe sources in SF and SP are crustal (wind-blown dust).

\section{The elution of selected trace metals in snow-firn pack}

Melting and percolation of water may influence the distribution of the chemical ions in the snow-firn pack (Brimblecombe and others, 1987; Eichler and others, 2001). At the PGPI sampling site, the elution of major soluble ions was found to be driven primarily by air temperature and became evident when a diurnal mean temperature of $-3.6^{\circ} \mathrm{C}$ was attained. At $0.3^{\circ} \mathrm{C}$, all year-round new ionic input was leached from the snow ( $\mathrm{Li}$ and others, 2006). Figure 4 shows variations of the mean concentrations of selected trace metals in the continuous SP. It can be seen that through autumn and into the winter the temperatureconcentration relation appears to be inverse. Meltwater percolation may have eluted elements through and from the $\mathrm{SP}$, transporting them downward via meltwater. However, this relation seems to break down from late winter into late spring, suggesting that the elution of ions via meltwater from a snowpack is a very dynamic process and warrants further study.

Table 2. Comparison of the average concentration of trace metals in UG1 with other selected areas

\begin{tabular}{|c|c|c|c|c|c|c|c|}
\hline \multirow[t]{3}{*}{ Location } & \multirow[t]{3}{*}{ Snow type } & \multirow[t]{3}{*}{ Time period } & \multicolumn{4}{|c|}{ Metal } & \multirow[t]{3}{*}{ Source } \\
\hline & & & $\mathrm{Pb}$ & $\mathrm{Cd}$ & $\mathrm{Zn}$ & Fe & \\
\hline & & & $\mathrm{pgg}^{-1}$ & $\mathrm{pgg}^{-1}$ & $\operatorname{pgg}^{-1}$ & $\operatorname{pgg}^{-1}$ & \\
\hline European Alps & Surface snow & 2000 & 68 & 13 & 1040 & 100000 & Veysseyre and others (2001) \\
\hline Greenland & Surface snow & 1995 & 108 & 4.5 & 207 & & Barbante and others (2003) \\
\hline UG1 & Surface snow & $2002-03$ & 2410 & 50 & 10000 & 130000 & This study \\
\hline
\end{tabular}




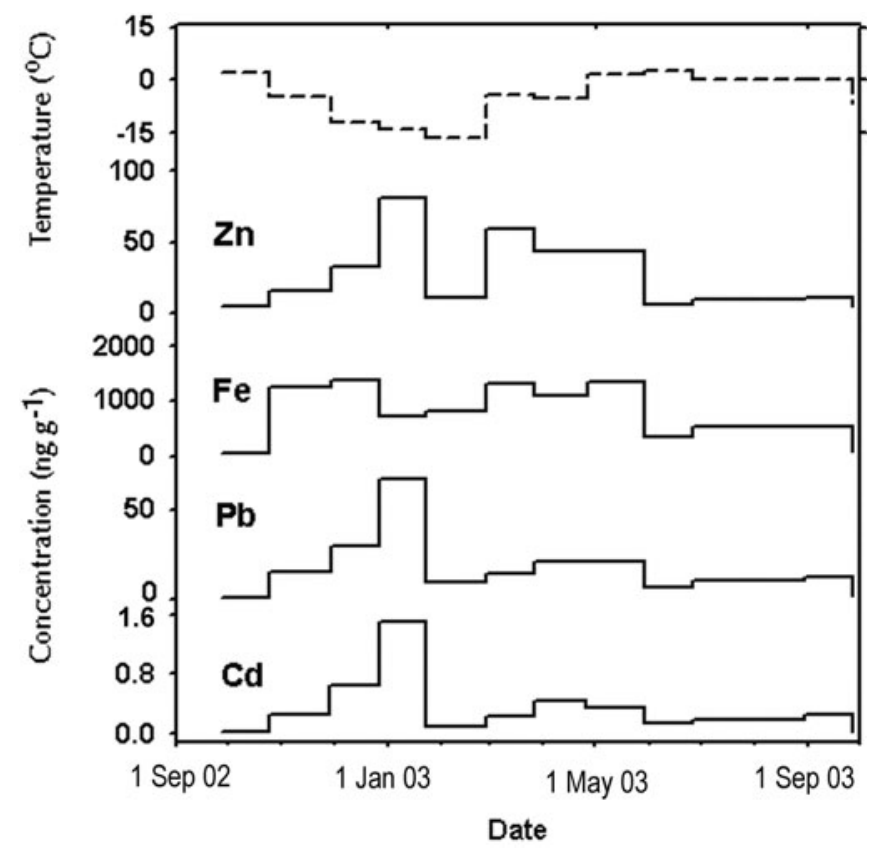

Fig. 4. The mean concentrations $\left(\mathrm{ngg}^{-1}\right)$ of $\mathrm{Pb}, \mathrm{Cd}, \mathrm{Zn}$ and $\mathrm{Fe}$ in the snow pits of UG1, and the variation of the mean air temperature $\left({ }^{\circ} \mathrm{C}\right)$ (shown by the dashed plot) for the same period.

In Figure 4, the concentrations of Fe are high through the late autumn and spring, with a decrease in the summer. For $\mathrm{Pb}, \mathrm{Cd}$ and $\mathrm{Zn}$, two concentration peaks are found, in January and around May 2003, with the magnitude of the latter being about half that of the former. However, the time for which values remain high is different for the three metals. Concentration values for $\mathrm{Pb}$ and $\mathrm{Cd}$, with similar characteristics, are high for shorter periods ( $>2$ months) than $\mathrm{Zn}$ values. Apparently the elution processes remove metals from the snow-firn, resulting in a remaining signal that can be underestimated in terms of concentration. This suggests that not only the deposition process but also post-depositional processes influence the concentration of the metals in the snow-firn pack.

\section{SUMMARY}

The concentrations of $\mathrm{Pb}, \mathrm{Cd}, \mathrm{Zn}, \mathrm{Al}$ and Fe shown here are the first data of their kind for SF and SP on UG1. The concentrations of the trace metals in surface snow (SF) show seasonal variation. High concentrations occur in autumn and winter, and low concentrations in summer. For $\mathrm{Pb}, \mathrm{Cd}$ and $\mathrm{Zn}$, a second peak occurs in the late spring and this may be caused mainly by wind-blown dust. The trace metal concentrations in snow-firn pits (SP) generally show an inverse relationship with the temperature, suggesting that elution processes during the warm summer months remove metals from the snow-firn. As a result, lower concentrations of the selected trace metals were found mainly in summer and early autumn; maximum concentrations were found in the winter, with values three to five times higher than the summer. A spatial comparison with other remote areas shows the concentrations of the selected trace metals at UG1 are much higher than polar and/or low-latitude remote areas. The crustal enrichment factors $\left(\mathrm{EF}_{\mathrm{C}}\right)$ for snow-firn pit samples were observed to range between 20 and 770 for almost all trace metals (except Fe), suggesting they may have non-crustal sources. The investigation of snow chemistry, particularly trace metals associated with pollution, in UG1 requires further study; more metals need to be investigated to evaluate the environmental impact of trace metals in surface snow and the snow-firn pack from anthropogenic sources in this area.

\section{ACKNOWLEDGEMENTS}

This research was supported by the Knowledge Innovation Project of the Chinese Academy of Sciences (KZCX2-YW127) and the National Natural Science Foundation of China (40571033, 40371028, J0630966). We thank P. Schuster and T. Hinkley for useful comments, helpful suggestions and language editing. Support for this research has been provided under the Program for Glacier Processes Investigation (PGPI) conducted by the Tianshan Glaciological Station (TGS), Chinese Academy of Sciences (CAS).

\section{REFERENCES}

Barbante, C. and 6 others. 1999. Trace element determination in alpine snow and ice by double focusing inductively coupled plasma mass spectrometry with microconcentric nebulization. J. Analy. Atom. Spectrom., 14(9), 1433-1438.

Barbante, C. and 8 others. 2001. Greenland snow evidence of large scale atmospheric contamination for Platinum, Palladium and Rhodium. Environ. Sci. Technol., 35(5), 835-839.

Barbante, C. and 7 others. 2003. Seasonal variations of heavy metals in central Greenland snow deposited from 1991 to 1995. J. Environ. Monitor., 5(2), 328-335

Barbante, C. and 14 others. 2004. Historical record of European emissions of heavy metals to the atmosphere since the $1650 \mathrm{~s}$ from alpine snow/ice cores drilled near Monte Rosa. Envir. Sci. Technol., 38(15), 4085-4090.

Boutron, C.F. 1990. A clean laboratory for ultralow concentration heavy metal analysis. Fresenius' J. Analy. Chem., 337(5), 482-491.

Boutron, C.F. and C.C. Patterson. 1986. Lead concentration changes in Antarctic ice during the Wisconsin/Holocene transition. Nature, 323(6085), 222-225.

Boutron, C.F., U. Görlach, J.P. Candelone, M.A. Bolshov and R.J. Delmas. 1991. Decrease in anthropogenic lead, cadmium and zinc in Greenland snows since the late 1960s. Nature, 353(6340), 153-156.

Brimblecombe, P., S.L. Clegg, T.D. Davies, D. Shooter and M. Tranter. 1987. Observations of the preferential loss of major ions from melting snow and laboratory ice. Water Res., 21(10), 1279-1286.

Candelone, J.P., S. Hong, C. Pellone and C.F. Boutron. 1995. PostIndustrial Revolution changes in large-scale atmospheric pollution of the northern hemisphere by heavy metals as documented in central Greenland snow and ice. J. Geophys. Res., 100(D8), $16,605-16,616$.

Chen, J. 1985. The preliminary research of the soil forming process in the glacier areas of Tianshan. Annual report on the work at Tianshan Glaciological Station, Lanzhou, Academica Sinica. Lanzhou Institute of Glaciology and Cryopedology, 4. [In Chinese.] 34-38.

Eichler, A., M. Schwikowski and H.W. Gäggeler. 2001. Meltwaterinduced relocation of chemical species in Alpine firn. Tellus, 53B(2), 192-203.

Ferrari, C.P. and 9 others. 2001. Heavy metals in ancient tropical ice: initial results. Atmos. Environ., 35(33), 5809-5815.

Halstead, M.J.R., R.G. Cunninghame and K.A. Hunter. 2000. Wet deposition of trace metals to a remote site in Fiordland, New Zealand. Atmos. Environ., 34(4), 665-676. 
Hinkley, T., F. Pertsiger and L. Zavjalova. 1997. The modern atmospheric background dust load: recognition in Central Asian snowpack, and compositional constraints. Geophys. Res. Lett., 24(13), 1607-1610.

Hong, S., A. Lluberas and F. Rodriguez. 2000. A clean protocol for determining ultralow heavy metal concentrations: its application to the analysis of $\mathrm{Pb}, \mathrm{Cd}, \mathrm{Cu}, \mathrm{Zn}$ and $\mathrm{Mn}$ in Antarctic snow. Korean J. Polar Res., 11(1), 35-47.

Lee, X., D. Qin, G. Jiang, K. Duan and H. Zhou. 2003. Atmospheric pollution of a remote area of Tianshan Mountain: ice core record. J. Geophys. Res., 108(D14), 4406. (10.1029/ 2002JD002181.)

Li, J. 1991. Climate of Xinjiang. Beijing, Meteorological Press. [In Chinese.]

Li, Y. and 6 others. 2006. Recent changes of atmospheric heavy metals in high-elevation ice core from Muztagh Ata, east Pamirs: initial results. Ann. Glaciol., 43, 154-159.

$\mathrm{Li}, \mathrm{Z}$., T. Yao and Z. Xie. 1995. Study on $\mathrm{SO}_{4}{ }^{2-}$ and $\mathrm{NO}_{3}{ }^{-}$ in atmospheric aerosol. Adv. Geosci., 10(1), 289-295. [In Chinese.]

Li, Z., G. Lu, B. Liu and H.Y. Fu. 1999. Ice core dust particulate by XPS-SEM/ED AX - impact of dust particulate on $\mathrm{SO}_{4}{ }^{2-}$ and $\mathrm{NO}_{3}{ }^{-}$ record in ice cores. Chinese Sci. Bull., 44(15), 1424-1427.

$\mathrm{Li}, \mathrm{Z}$. and 9 others. 2006. Seasonal variability of ionic concentrations in surface snow and elution processes in snow-firn packs at the PGPI site on Ürümqi glacier No. 1, eastern Tien Chan, China. Ann. Glaciol., 43, 250-256.

Luo, H. 1983. Hydrochemical features of the Glacier No.1 in the source region of Ürümqi River, Tian Shan. J. Glaciol. Geocryol., 5(2), 55-64. [In Chinese with English abstract.]

Murozumi, M., T.J. Chow and C.C. Patterson. 1969. Chemical concentration of pollutant lead aerosols, terrestrial dusts and sea salts in Greenland and Antarctic snow strata. Geochim. Cosmochim. Acta, 33(10), 1247-1294.

$\mathrm{Ng}, \mathrm{A}$. and C. Patterson. 1981. Natural concentrations of lead in ancient Arctic and Antarctic ice. Geochim. Cosmochim. Acta, 45(11), 2109-2121.

Qin, D., P.A. Mayewski, W.B. Lyons, J. Sun and S. Hou. 1999. Lead pollution in Antarctic surface snow revealed along the route of the International Trans-Antarctic Expedition. Ann. Glaciol., 29, 94-98.
Reimann, C. and P. de Caritat. 2000. Intrinsic flaws of element enrichment factors (EFs) in environmental geochemistry. Envir. Sci. Technol., 34(24), 5084-5091.

Van de Velde, K. and 6 others. 1998. Seasonal variations of heavy metals in the 1960s Alpine ice: sources versus meteorological factors. Earth Planet. Sci. Lett., 164(3-4), 521-533.

Van de Velde, K. and 6 others. 1999. A 200 year record of atmospheric cobalt, chromium, molybdenum, and antimony in high altitude Alpine firn and ice. Envir. Sci. Technol., 33(20), 3495-3501

Van de Velde, K. and 8 others. 2000. A two hundred years record of atmospheric Cadmium, Copper and Zinc concentrations in high altitude snow and ice from the French-Italian Alps. Geophys. Res. Lett., 27(2), 249-252.

Veysseyre, A. and 7 others. 2001. Heavy metals in fresh snow collected at different altitudes in the Chamonix and Maurienne valleys, French Alps: initial results. Atmos. Environ., 35(2), 415-425.

Wake, C.P., P.A. Mayewski, P. Wang, Q. Yang, J. Han and Z. Xie. 1992. Anthropogenic sulfate and Asian dust signals in snow from Tien Shan, northwest China. Ann. Glaciol., 16, 45-52.

Wang, D. and P. Zhang. 1985. On the valley climate of Ürümqi River in the Tianshan Mountains. J. Glaciol. Geocryol., 7(3), 239-248. [In Chinese with English abstract.]

Wang, F. and others. 2006. Seasonal evolution of aerosol stratigraphy in Ürümqi glacier No. 1 percolation zone, eastern Tian Shan, China. Ann. Glaciol., 43, 245-249.

Wedepohl, K.H. 1995. The composition of the continental crust. Geochim. Cosmochim. Acta, 59(7), 1217-1232.

Wolff, E.W. 1990. Signals of atmospheric pollution in polar snow and ice. Antarct. Sci., 2(3), 189-205.

Wolff, E.W., M.R. Legrand and D. Wagenbach. 1998. Coastal Antarctic aerosol and snowfall chemistry. J. Geophys. Res., 103(D9), 10,927-10,934.

Xiao, C.D., D.H. Qin, T.D. Yao, J.W. Ren and Y.F. Li. 2001. Spread of lead pollution over remote regions and upper troposphere: glaciochemical evidence from polar regions and Tibetan Plateau. Bull. Environ. Contam. Toxicol., 66(6), 691-698.

Zhang, Y., E. Kang and C. Liu. 1994. Mountain climate analysis in Ürümqi River valley, Tianshan. J. Glaciol. Geocryol., 16(4), 333-341. [In Chinese.] 